\title{
AZ AMERIKAI ELNÖKVÁLASZTÁS HATÁSA AZ ÉGHAJLATVÁLTOZÁS ELLENI KÜZDELEMRE *
}

\author{
Lovas Dóral
}

A 2016 novemberében zajló amerikai elnökválasztás eredménye döntö jelentőséggel bír a globális felmelegedés elleni küzdelemben. Sokakban felmerül a kérdés, hogy Donald Trump elnökké választásának milyen hatása lesz az USA nemzetközi klímavédelmi kötelezettségvállalásaira. Míg Barack Obama (2009-2017) elkötelezett híve volt az üvegházhatású gázok kibocsátás-csökkentésének, addig Trump az USA versenyképességének javitását és gazdaságának növelését ösztönzi, háttérbe szorítva az éghajlatváltozás elleni küzdelmet.

A klímavédelemmel nemzetközi szinten az 1970-es években kezdtek el foglalkozni, amikor felfedezték, hogy vannak olyan mesterséges/emberek által elöállított anyagok, amelyek ózonréteg bontó hatással bírnak. A 43/53 ENSZ közgyülési határozat e problémát már, mint az „emberiség közös gondját” határozza meg. Ezt követően több nemzetközi egyezmény született az ózonréteg védelme érdekében, amely törekvésekkel párhuzamosan az Európai Közösség is fontosnak tartotta az Egyezményekben felsorolt vegyi anyagok elleni közösségi küzdelmet.

Az első globális felmelegedés elleni nemzetközi jogi dokumentum (Éghajlat változási Keretegyezmény) az ENSZ égisze alatt 1992-ben született meg aRio de Janeiróban tartott Környezet és Világkonferencián. A dokumentum célja: ,,az üvegházgázok légköri koncentrációinak stabilizálása olyan szinten, amely megakadályozná az éghajlati rendszerre gyakorolt veszélyes antropogén hatást. ${ }^{, 2}$ A Keretegyezmény részes államai ezt követően több konferenciát hívtak össze a korábban megfogalmazott célok elérése érdekében, azonban nem sikerült számottevő eredményeket elérniük.

1997 sorsfordító évnek tekinthető a globális felmelegedés elleni küzdelem szempontjából, mivel megszületett a fejlett országokat tömörítő Kiotói Egyezmény, amelyben az aláíró államok kötelezik magukat arra, hogy széndioxid-kibocsátásukat 2012-ig 5,2 százalékkal az 1990-es szint alá szorítják vissza. Az egyezmény 2005. február 16-án lépett hatályba, és 2006. decemberéig csaknem a világ széndioxidkibocsátásának 61.6 százalékáért felelős 169 állam csatlakozott. Sajnos az USA és Ausztrália nem vett részt az egyezményben, Kanada pedig utóbb felmondta azt. A Jegyzőkönyv aláírását az akkori amerikai elnök,George Bush azért utasította vissza, mivel véleménye szerint a fejlődő országok ÜHG kibocsátását is korlátozni kellene, nemcsak a fejlett államoknak kellene kibocsátás-csökkentési kötelezettséget vállalniuk és figyelemmel kell lenni a vállalt kötelezettségek az USA gazdaságára gyakorolt hatásaira is.

\footnotetext{
* DOI 10.21867/KjK/2017.1.6.

${ }^{1}$ Dr. Lovas Dóra, PhD hallgató DE-ÁJK

${ }^{2}$ ENSZ Éghajlatváltozási Keretegyezmény
} 
Problémaként említhető meg továbbá, hogy más nagy ÜHG kibocsátók, mint például India vagy Kína csatlakoztak ugyan a Kiotói Egyezményhez, ám részükre kivételes bánásmódot biztosít a dokumentum, így nekik a jegyzőkönyv alapján nem szükséges a széndioxid-kibocsátásukat visszafogniuk.

Éppen ezen utóbbi megállapítások miatt az egyezmény hatékonysága vitatott. Az Európai Unió már a kezdetektől úgy képzeli el az éghajlatváltozás elleni küzdelemre vonatkozó nemzetközi dokumentumokban vállalt célkitüzések teljesítését, hogy a tagállamok által közösen vállalt kibocsátási célokat egy közös rendszerbe foglalja és valósítja meg. ${ }^{3}$

2009-ben az USA elnöke Barack Obama lett, aki elnöki ciklusának végéig négy célt tüzött ki maga elé, így az amerikai gazdaság felpörgetését, az USA Irakból való kivonulását, az egészségügy reformját és az éghajlatváltozás elleni küzdelemre vonatkozó lépéseket.

Ugyanebben az évben került sor a Koppenhágai konferenciára is, ahol olyan fontos kérdésekről egyeztettek az államok, mint a 2012-2020 közti időszak globális klímaszabályozása, illetve a fejlődő országok kibocsátás-csökkentés mértékének meghatározása. E konferencia azonban nem zárult sikeresen, mindössze annyit sikerült elérniük, hogy célként kitüzzék az 1997-es Kiotói jegyzőkönyvet felváltó, újabb egyezmény kialakítását, amelyhez már az USA is csatlakozna, illetve amelyben a CO2kibocsátási kvóták beszámításáról születnének szabályok. ${ }^{4}$

Obamának az elnöki ciklus végére csak az első három célkitüzésben sikerült előrelépést véghezvinnie, tekintettel a Koppenhágai konferencia sikertelenségére, valamint arra, hogy az általa eltervezett klímatörvényt nem sikerült keresztülvinnie sem a képviselöházon, sem pedig a republikánus többségü szenátuson. Emiatt második elnöksége idején fő prioritásának a negyedik cél megvalósítását tartotta. Elhatározta, hogy elnöki végrehajtási aktusa segítségével és a „környezetvédelmi minisztériuma” (EPA)által kibocsátott rendeleteken keresztül fogja megvalósítani az éghajlatváltozás elleni küzdelemre vonatkozó célkitüzéseit. 2012-ben tett ígérete szerint az országban 2020-ig 17 százalékkal csökkenti majd az erőmüvek károsanyag-kibocsátását,illetve az USA nemzetközi klímatárgyalások vezetőjeként fog részt venni. $\mathrm{E}$ prioritás megfogalmazásával azonban Obama nagy kockázatot vállalt, mivel a legszennyezőbb erőmüvek gyakran a legjövedelmezőbb vállalatok közé tartoznak, amelyek sokat költenek kormányzati lobbira.

2013-ban az elnök saját hatáskörében utasította az Environmental Protection Agency-t (EPA), hogy dolgozzon ki az áramtermelő erőmüvek kibocsátás-csökkentésére vonatkozó szabályozást, a tagállamoknak széles mozgásteret hagyva a csökkentés elérésének módjában. A szabályozás azért az áramtermelö erőmüvekre koncentrál, mivel azok fogyasztása az USA-ban igen magas, és az üvegházhatású gázok egyharmada az áramtermelés során kerül a levegőbe. A rendelet célul tüzte ki, hogy az

\footnotetext{
${ }^{3}$ Zöld Könyv(2006): Európai Stratégia az energiaellátás fenntarthatóságáért, versenyképességéert, és biztonságáért.

${ }^{4}$ Dr. Csegődi Tibor László (szerk.): Környezetvédelem és Klímajog , egyetemi jegyzet; Gödöllö, 2012.167-180.old.
} 
amerikai kormányzat kezelésében álló cégek és intézmények 2025-re összességében 40 százalékkal csökkentsék az üvegházhatást kiváltó gázok kibocsátását az 1980-as szinthez képest, valamint, hogy a teljes energiafelhasználás 30 százalékát megújuló energiaforrásból biztosítsák majd. Ez a kötelezettségvállalás többek között a jármüvek és a berendezések üzemanyag-felhasználási hatékonyságára vonatkozó elöírásokra, az EPA az erőmüvek széndioxid- és a gáz- és olajszektor metángáz-kibocsátására vonatkozó szabályozására és elnöki rendeletekre támaszkodik. ${ }^{5}$

Mivel Obama a végrehajtási utasítás eszközével élt, annak nem kell végigmennie a szokásos törvényhozási eljáráson (nem kell elfogadnia a szenátusnak, illetve kongresszusnak). A rendelet szerinti végleges szabályozás 2015-re készült el és az államoknak 2017 nyaráig kell benyújtaniuk a végrehajtásra vonatkozó terveiket, így leghamarabb 2018-ban indulhatnak konkrét lépések az új szabályozás terén. ${ }^{6}$

Az ENSZ keretében évente megrendezésre konferenciák közül a 24. eredményesen zárult, mivel ennek alkalmával, 2015. december 12-én új megállapodást sikerült elfogadni (Párizsi Megállapodás és Határozat). A Megállapodás legfontosabb céljai között szerepel, hogy a globális átlaghőmérséklet-emelkedés ne érje el a +2 Celsiusfokot (az ipari forradalom előtti időkhöz képest), valamint megpróbálják az átlaghőmérséklet-emelkedést mindössze $+1,5$ fokon tartani.

Fontos kiemelni a különbséget az 1992-es, az 1997-es, a 2012-es és a 2015 egyezmények között. Először, 1992-ben a fejlett országok azt vállalták, hogy egy korábbi általuk meghatározott évhez képest 2000-ben nem fognak több ÜHG-t a légkörbe engedni (,,közös, de megkülönböztetett felelösség elve” - fejlett és fejlődő országok között). A Kiotói Jegyzőkönyvben a fejlett országok azt vállalták, hogy átlagosan 5\%-os csökkentést érnek el 2012-ig. A Jegyzőkönyv elfogadását követően azonban nemzetközi elemzések kimutatták, hogy az üvegházhatású gázok kibocsátásai továbbra is növekedtek és ahhoz minél inkább hozzájárultak a növekvő gazdaságú fejlődő országok. A most még nem hatályos Dohai Módosításban (Japán, Kanada, Oroszország, Új-Zéland és az USA kivételével) a fejlett országok 2020-ig vállalták kibocsátásaik csökkentését. Ezt az EU-s tagállamok aláíták, de ez a módosítás a mai napig nem lépett hatályba. ${ }^{7}$

A 2015-ben elfogadott Párizsi Megállapodás és Határozat címzetti köre egyetemes, azaz a fejlett és fejlödő országokra egyaránt vonatkozik. A Határozatban szó van a 2020-ig teljesítendő konkrét feladatokról, a Megállapodás hatálybalépéséig ellátandó tevékenységek szervezeti és adminisztratív teendőiröl. E dokumentum szerint fontos a Dohai Módosítás minél hamarabbi hatálybalépése és végrehajtása, valamint az, hogy a fejlett országok még nagyobb mértékben csökkentsék károsanyag-kibocsátásaikat .Az Egyezmény megítélése még számos kérdést von maga után, mivel nem lehet tudni, hogy ez alapján megvalósítható-e a globális éghajlat-változási folyamat megfékezése, valamint mind a Határozat, mind pedig a Megállapodás több nem kellően részletezett

\footnotetext{
${ }^{5}$ http://regithink.transindex.ro/?tag=barack-obama, (letöltés ideje: 2016. 12. 27.)

${ }^{6}$ Fülöp Orsolya: Emisszionárius póz - Mégis klímaharcos lesz az USA? https://www.energiaklub.hu/blog/emisszionarius-poz-megis-klimaharcos-lesz-az-usa, (letöltés ideje: 2016.12. 26.)

${ }^{7}$ Faragó Tibor: Új nemzetközi éghajlatvédelmi megállapodás; Magyar Energetika, 2015 XXII.5-6., 5861.
} 
rendelkezést tartalmaz (ezt további tárgyalások fogják tisztázni). A Megállapodásban foglaltak teljesülésének értékelésére nyolc év múlva kerül majd sor, azonban a siker előfeltétele, hogy a Dohai Módosításban érintett fejlett országok teljesítik e majd a kibocsátás csökkentési vállalásaikat, valamint a fejlett országok eleget tesznek-e a fejlődő országoknak ígért pénzügyi támogatásnak. ${ }^{8}$

Obama második elnökségi ciklusa utolsó évében a Párizsi Megállapodás alapján elkészült az amerikai Szándékozott Nemzetileg Meghatározott Hozzájárulás (INDC), amely szélesebb értelemben megfogalmazott célkitűzéseket tartalmaz, mint az Európai Unió dokumentumában meghatározottak, mivel ezen utóbbi konkrétan megfogalmazza, hogy a közlekedésben, az energetikában és az iparban mekkora csökkentést irányoz előre, illetve emellett célul tüzi ki a megújuló energiaforrásra történő fokozatos áttérést.

Az USA több állama (a szén-, kőolaj- és palagáz-kitermelésben érdekeltek) és vállalata megtámadta az éghajlatváltozás elleni küzdelemre vonatkozó célokat előíró EPA rendeleteket (gyüjtőnevén a Tiszta Energia Tervet) a Legfelsőbb Bíróság előtt, amely 2016 februárjában felfüggesztette a rendeletek végrehajtását, amelyben komoly szerepe volt a konzervatív bírák többségének. A megtámadási keresetet benyújtók jogszerütlennek ítélték a szabályozást, azonban érvként csak a gazdasági veszteségeikre hivatkoztak. Ez azért is volt meglepő döntés, mivel éppen a Legfelsőbb Bíróság volt az, mely felkérte az EPA-t, hogy szabályozza a Tiszta Levegő Törvény hatálya alatt a széndioxid-kibocsátást, ha a tudósok kimutatják, hogy az üvegházhatású gázok kibocsátása ártalmas az amerikai nép egészségére.

A bíróság döntése alapján felfüggesztették a rendeletek végrehajtását, amíg ki nem vizsgálják a rendeleteket megtámadók érvét a gazdasági csökkenésre vonatkozóan. Nem hagyható figyelmen kívül azonban, hogy mindenhol az építőipar, és az energiaszektor tartoznak a legnagyobb károsanyag-kibocsátók közé, amelyek törvényi erejü visszaszorítása elengedhetetlen akibocsátás-csökkentés megvalósításához.

A felfüggesztés eredménye leghamarabb 2017-ben várható, amikor már Donald Trump kezdi meg elnöki mandátumát. Előreláthatólag ő nem folyatja majd elödje klímavédelmi politikáját, mivel a republikánus politikai fősodor képviselőjeként klímaváltozás-tagadó és az olaj-lobbi érdekeit képviseli. ${ }^{9}$

Egyébként 2016 szeptemberében Obama és Hszi Csin-ping kínai államfő ratifikálták a Párizsi Megállapodást, így összesen 25 ország írta alá eddig (amelyek a világ károsanyag-kibocsátásának kb.39-41\%-át adják). Az egyezmény akkor lép hatályba, ha legalább 55 állam ratifikálja, amelyek együttesen a globális felmelegedést okozó anyagok kibocsátásának 55 százalékáért felelősek. Hatálybalépése azonban kérdéses...

\section{Éghajlatváltozás, mint létező probléma?}

\footnotetext{
${ }^{8}$ Faragó Tibor: A párizsi klímatárgyalások eredményei;Magyar Energetika, 2016/1, 8-12.o

${ }^{9}$ http://www.piacesprofit.hu/klimablog/hatraltatja-a-birosag-a-klimavedelmet-obama-utodjatol-fugg-afolytatas/ (letöltés ideje: 2016. 12. 27.)
} 
2017-től Donald Trump lett az USA új elnöke, akinek prioritásai között nem szerepel az éghajlatváltozás elleni küzdelem. Beiktatására január 20-án került sor, amellyel egyidőben a Fehér Ház honlapját is frissítették. A weboldalon a frissítést követően a klímaváltozás után érdeklődő nem talál a témához kapcsolódó információt, holott Obama idején annak egy külön oldalt szenteltek, és számos információt lehetett olvasni a globális felmelegedés ellen tett amerikai és nemzetközi lépésekről.

$\mathrm{Az}$ új elnök e lépése azonban nem okozott meglepetést, mivel kampánya idején többször hangoztatta, hogy a klímaváltozás nem létezik, azt csupán Kína találta ki, azért, hogy rontsa az USA versenyképességét. ${ }^{10}$

\section{Két elnök-két ellentétes elképzelés}

Míg Obama elutasította a Keystone XL-olajvezeték megépítését (több helyen, környezetvédelmi területen haladt volna át), aláírta a Párizsi Megállapodást (2016 szeptemberében ratifikálta azt), végrehajtói hatalmával élve, előírta az üvegházhatást okozó gázok kibocsátásának csökkentését, továbbá több szövetségi bányászati projektet is leállított (föleg Virginia és Texas államok hátrányára). Ezzel szemben Trump terve, hogy visszavonja a Legfelsőbb Bíróság által 2016 februárjában felfüggesztett széndioxid-kibocsátásra vonatkozó elnöki végrehajtói intézkedést, az Obama által elutasított Keystone XL gázvezetéket megépítse, eltörölje a Párizsi Megállapodást, kiterjessze a tengeri olajfúrást és felélessze a szénbányászatot.

\section{Trump megválasztásának hatásai a Párizsi Megállapodásra}

Amennyiben az új elnök a Párizsi Megállapodásban foglalt kibocsátás-csökkentési kötelezettségeit újratárgyalná, esélyt adna a fejlődő országok számára is, hogy visszavonják vállalásaikat és új enyhébb kötelezettségeket irányozzanak elő.

A Megállapodás USA és Kína általi ratifikációja előrelépést jelentett a klímavédelem területén, tekintve, hogy e két ország felel a világ összes károsanyag-kibocsátásának kb. $38 \%$-áért, és az egyezmény akkor lép hatályba, ha legalább annyi állam ratifikálja, amely annak 55\%-áért felelös (és egyidejüleg legalább 55 állam). Így ha az Amerikai Egyesült Államok felmondaná a Megállapodást, annak hatálybalépése lehetetlenné válna. Trump e döntését attól teszi függővé, hogy Kína hajlandó-e nagyobb felelösséget és kibocsátás-csökkentést vállalni (eddigi vállalása az, hogy2030-ra kibocsátása növekedését csökkenti), mivel véleménye szerint a globális felmelegedést Kína találta ki, hogy ártson az USA gazdaságának, versenyképességének.

A párizsi klímaegyezmény megengedi, hogy egy részes állam 4 év eltelte után a felmondás lehetőségével éljen, azonban ez a rendelkezés számos vitás pontot vett fel. Így például kérdéses, hogy az új elnök mennyire érzi Amerikára nézve kötelezőnek ezt a rendelkezést,mert (felmondás nélkül) pusztán azzal is tehet a vállalt kötelezettségek ellen, hogy nem tesz semmit az egyezmény megvalósulása érdekében. Továbbá felvetődik az a kérdés is, hogy a felmondási időként megállapított négy évet, honnantól kezdve kell számolnunk, mivel ha az aláírástól kezdődik, akkor Trumpnak egy éve lesz

\footnotetext{
${ }^{10}$ http://hvg.hu/vilag/20170120_Trump_elso_intezkedese_megszuntette_a_klimavaltozast $\quad$ (letöltés ideje: 2017. 01.20.)
} 
annak megtételére, ha azonban az a ratifikálás időpontja, akkor lejárhat a mandátuma a 4 év elteltéig, és így nem tud tenni az egyezmény ellen. ${ }^{11}$

A fentiek alapján megállapítható, hogy az Európai Unió és annak tagországai, valamint Japán élen járnak az üvegházhatást okozó gázok kibocsátásának csökkentésében. Az Egyesült Államok, a világ második legnagyobb szennyezőanyagkibocsátója továbbra sem hajlandó komolyabb felelösséget vállalni az éghajlatváltozás elleni küzdelemben. Barack Obamának második elnöksége alatt sikerült számottevő eredményeket elérnie a klímavédelem területén, azonban utódja, Donald Trump meghiúsíthatja az elődje által elindított eredményes folyamatot. Az, hogy a korábbi elnök klímavédelem területén elért eredményeit utódja mennyiben tudja és akarja véghezvinni, egyelöre a jövő titka, az azonban bizonyos, hogy az új elnök nem olyan elkötelezett híve a globális felmelegedés elleni küzdelemnek.

\section{Források:}

ENSZ Éghajlatváltozási Keretegyezmény

Zöld Könyv (2006): Európai Stratgia az energiaellátás fenntarthatóságáért, versenyképességéért, és biztonságáért.

Dr. Csegődi Tibor László (szerk.): Környezetvédelem és Klímajog -egyetemi jegyzet-; Gödöllő,2012. 167-180.old.

http://regithink.transindex.ro/?tag=barack-obama, letöltés ideje: 2016. december 27.

Fülöp Orsolya: Emisszionárius póz - Mégis klímaharcos lesz az USA?

https://www.energiaklub.hu/blog/emisszionarius-poz-megis-klimaharcos-lesz-az-usa

Faragó Tibor: Új nemzetközi éghajlatvédelmi megállapodás; Magyar Energetika, 2015 XXII.5-6., 58-61.

Faragó Tibor: A párizsi klímatárgyalások eredményei; Magyar Energetika, 2016/1,812.0.

http://www.piacesprofit.hu/klimablog/hatraltatja-a-birosag-a-klimavedelmet-obamautodjatol-fugg-a-folytatas/

http://www.piacesprofit.hu/klimablog/trump-felrugna-a-klimaegyezmenyt/ http://hvg.hu/vilag/20170120_Trump_elso_intezkedese_megszuntette_a_klimavaltozast

\footnotetext{
${ }^{11}$ http://www.piacesprofit.hu/klimablog/trump-felrugna-a-klimaegyezmenyt/; letöltés ideje: 2016.december 27.
} 